\title{
Biosorption kinetics of a direct azo dye Sirius Blue K-CFN by Trametes versicolor
}

\author{
Emre Erden ${ }^{1} \cdot$ Yasin Kaymaz $^{1} \cdot$ Nurdan Kasikara Pazarlioglu $^{1} \square$ \\ 1 Biochemistry Department, Faculty of Science, Ege University, Bornova, Izmir, Turkey
}

$\triangle$ Corresponding author: nurdan.pazarlioglu@ege.edu.tr
Received September 21, 2010 / Accepted January 17, 2011
Published online: March 15, 2011
(C) 2011 by Pontificia Universidad Católica de Valparaíso, Chile

\begin{abstract}
In this study, lyophilized Trametes versicolor biomass is used as a sorbent for biosorption of a textile dye, Sirius Blue K-CFN, from an aqueous solution. The batch sorption was studied with respect to dye concentration, adsorbent dose and equilibrium time. The effect of $\mathrm{pH}$ and temperature on dye uptake was also investigated and kinetic parameters were determined. Optimal initial pH (3.0), equilibrium time $(2 \mathrm{hrs})$, initial dye concentration $\left(100 \mathrm{mg} \mathrm{l}^{-1}\right)$ and biomass concentration $\left(1.2 \mathrm{mg} \mathrm{I}^{-1}\right)$ were determined at $26^{\circ} \mathrm{C}$. The maximum biosorption capacity $\left(q_{\max }\right)$ of Sirius Blue K-CFN dye on lyophilized $T$. versicolor biomass is $62.62 \mathrm{mg} / \mathrm{g}$. The kinetic and isotherm studies indicated that the biosorption process obeys to a pseudo-second order model and Langmuir isotherm model. In addition, the biosorption capacities of fungal biomass compared to other well known adsorbents such as activated carbon and Amberlite, fungal biomass biosorptions capacities were found to be more efficient.
\end{abstract}

Keywords: biosorbent, biosorption, direct dye, kinetics, Sirius Blue K-CFN, Trametes versicolor

\section{INTRODUCTION}

Approximately 700,000 tones and 10,000 different types of dyes and pigments are produced annually across the world and are extensively used in many industries including textile, leather, pulp, paper, food and plastics (Sadettin and Dönmez, 2006; Kiran et al. 2009; Aksakal and Ucun, 2010). Among all the chemical available dye classes, direct azo dyes are water-soluble molecules containing one or more ionic groups (most often sulfonic acid and/or amino groups) and are considered to be recalcitrant, non-biodegradable and persistent (Mohan et al. 2008; Akar et al. 2009). A significant proportion of these dyes is lost in manufacturing and processing units and enter the environment in wastewater. The colored dye effluents are considered to be highly toxic to the aquatic biota and affect the symbiotic process by disturbing the natural equilibrium through reducing photosynthetic activity and primary production due to the coloration of the water in streams (Aksu and Tezer, 2005).

Physico-chemical processes such as electro-coagulation, ozonation, photocatalysis, membrane filtration and adsorption have been employed for the treatment of dye containing wastewater (Patel and Suresh, 2008). Among these technlogies the adsorption method is widely used in the removal of synthetic dyes from the industrial effluent (Calvete et al. 2009; Liang et al. 2010). Through the great variety of adsorbents, activated carbon and ion exchange resins have been investigated for removing the dye from wastewater. Although they have a good adsorption capacity, their high costs limit the commercial application (unit cost of virgin material is about 1 US dolar $/ \mathrm{kg}$ ) as well as activated carbon can not be regenerated easily (thermal regeneration costs are about 1-2 US dolar/kg) (Russo et al. 2010). Therefore, new, low-cost and highly effective sorbents need to be investigated.

Biosorption process employing biopolymers (such as sawdust, wood chips, chitin/chitosan, starch, cyclodextrin and cross linked chitosan/cyclodextrin) and non-viable microbial (fungi, algae and bacteria) biomass has emerged as one of the powerful and attractive option since it is inexpensive, 
effective and simple to operate and it also possesses good mechanical properties against abrasion (Crini, 2006; Kumari and Abraham, 2007; Maurya et al. 2006; Renganathan et al. 2006; Batzias and Sidiras, 2007).

Biosorption is becoming a promising alternative to replace or supplement the present dye removal processes from dye wastewaters (Fu and Viraraghavan, 2003). It involves binding of pollutants to the surface of cell membranes and/or cell walls through physical adsorption, electrostatic interaction, ion exchange, chelation and chemical precipitation (Aksu, 2005).

Bhole et al. (2004) studied the effect of different parameters on sorption of methyl violet, basic fuchsin and their mixture in an aqueous solution. They used dead biomass of Aspergillus niger and observed that fungal biomass was an efficient biosorbent. Perumal et al. (2007) investigated the rate and efficiency of decolorization of dyes like Blue CA, Black B133, and Corazol Violet SR by white rot fungal strains. They found that Trametes hirsute and Pleurotus florida showed the greatest extent of decolorization on nutrient salt media.

Although there are several dye biodegradation studies by Trametes versicolor (Bayramoglu and Arica, 2007; Yang et al. 2009; Pazarlioglu et al. 2010), in this study, biosorption of a textile dye, Sirius Blue KCFN, onto lyophilizated $T$. versicolor pellets was investigated in batch system for the first time. Various parameters including effects of $\mathrm{pH}$ and temperature on dye uptake was examined and also kinetic and isotherm studies were conducted to evaluate the adsorption capacity of $T$. versicolor biomass.

\section{MATERIALS AND METHODS}

\section{Preparation of fungal biomass}

The white rot fungus Trametes versicolor FPRL 28A IMI (EGHAM SURVEY) was maintained on 2\% $(\mathrm{w} / \mathrm{v})$ malt extract agar slants at $4^{\circ} \mathrm{C}$ and the fungus was activated at $26^{\circ} \mathrm{C}$, for four days. The mycelium were harvested with sterile $0.9 \% \mathrm{NaCl}$ solution and then inoculated into $100 \mathrm{ml} 2 \%$ malt extract broth in $250 \mathrm{ml}$ Erlenmeyer flasks at $26^{\circ} \mathrm{C}$ and $175 \mathrm{rpm}$ for 4 days. Cultivation was carried out in an orbital shaker. After the growth period of $T$. versicolor, pellets were autoclaved at $121^{\circ} \mathrm{C}$, during $15 \mathrm{~min}$. The biomass separated from broth by filtration and washed with $0.9 \% \mathrm{NaCl}$ solution. Fungal biomass was lyophilized and pounded in order to increase the surface area and used as adsorbent.

\section{Preparation of dye solution}

Sirius Blue K-CFN (synonym; Direct Blue 9, C.I. 24155, $\left(\lambda_{\max }=583 \mathrm{~nm}\right.$ ), is a direct dye and its chemical structure is given in Figure 1.

Dye was dissolved in distilled water at a desired concentration. The $\mathrm{pH}$ of each solution was adjusted to the required value with $1 \mathrm{M} \mathrm{HCl}$ and $1 \mathrm{M} \mathrm{NaOH}$ solutions.

\section{Batch biosorption studies}

The biosorption of Sirius Blue K-CFN were investigated in a batch system at different $\mathrm{pH}$ values, temperature, biomass concentration and contact time to determinate the rate constant and extent of dye uptake by the biosorbent.

The effect of initial concentrations of the dye on the biosorption rate and capacity was determined in the range 5-500 $\mathrm{mg} \mathrm{I}^{-1}$ dye concentration. The effects of the initial $\mathrm{pH}$ on the biosorption capacity were investigated in the $\mathrm{pH}$ range of 2.0-7.0. The effect of temperature on biosorption capacity was studied at five different temperatures, $7,15,26,35$ and $45^{\circ} \mathrm{C}$, and at initial $\mathrm{pH} 3.0$. The effect of biosorbent mass on biosorption process was obtained by using different biomass concentrations (i.e., $0.8,1.0$ and $\left.1.2 \mathrm{gl}^{-1}\right)$. 


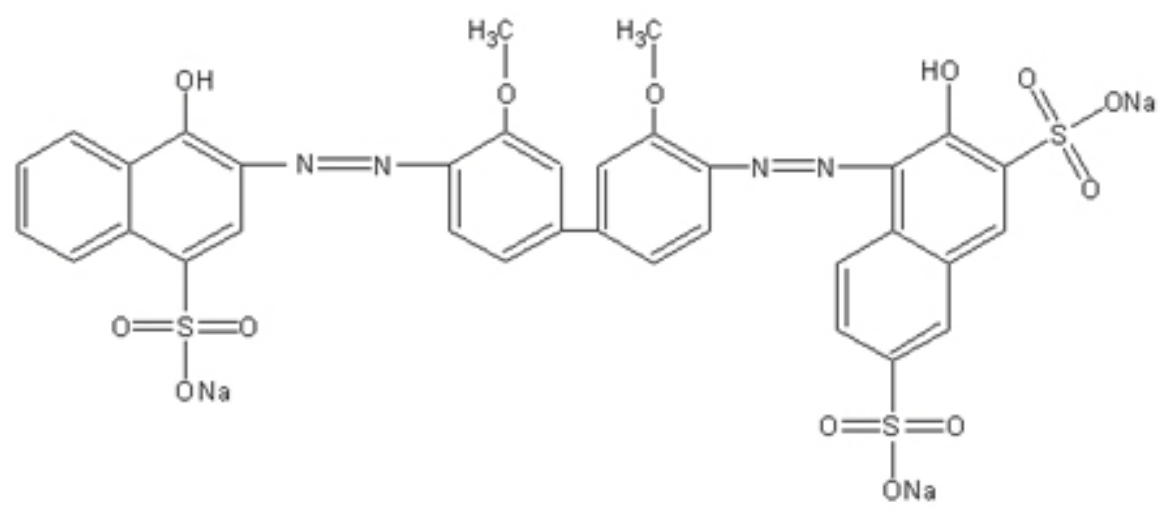

Fig. 1 Chemical structure of Sirius Blue K-CFN.

Typical biosorption experiment was conducted in Erlenmeyer flasks containing $1.2 \mathrm{~g} \mathrm{I}^{-1}$ of biomass with $100 \mathrm{mg} \mathrm{l}^{-1}$ dye solution at $26^{\circ} \mathrm{C}$. The flasks were agitated on an orbital shaker at $150 \mathrm{rpm}$ for $5 \mathrm{hrs}$ to ensure equilibrium.

Before analyzing the remaining dye solution, biomass was removed from solution by centrifugation at $4000 \mathrm{rpm}$ for $15 \mathrm{~min}$ and dye concentration of the supernatant was determined.

\section{Analysis of dye}

The concentration of unadsorbed Sirius Blue K-CFN was determined spectrophotometrically using a JascoUV/VIS spectrophotometer $\left(\lambda_{\max }=583 \mathrm{~nm}\right)$.

\section{Comparison with activated carbon and Amberlite XAD-7}

In this study, to make a comparison with prepared biomass and the commercial adsorbents such as activated carbon, the most known sorbent, and Amberlite XAD-7, polymeric resin which is moderately polar, were also used for the dye biosorption. This comparative study was conducted by treating 100 $\mathrm{mg} \mathrm{l}^{-1}$ of final dye solution with $1.2 \mathrm{~g} \mathrm{I}^{-1}$ of the lyophilized $T$. versicolor biomass at the $\mathrm{pH}$ 3.0. All experiments were performed in triplicate and the mean was calculated.

\section{RESULTS AND DISCUSSION}

\section{Effect of initial pH on dye biosorption}

Textile dyes are complex organic compounds having different aromatic rings and functional groups; the latter have different ionization potentials at different $\mathrm{pH}$ and therefore their interaction with microbial biomass depends on the chemistry of a particular dye and the specific chemistry of the biosorbents (Yesilada et al. 2003). The ionic forms of the dye in solution and the surface electrical charge of the biomass depend on the solution $\mathrm{pH}$ (Maurya et al. 2006). Therefore, $\mathrm{pH}$ significantly influences the dye biosorption. The effect of the $\mathrm{pH}$ on dye biosorption is presented in Figure 2. As seen from the figure, the maximum dye biosorption was observed at $\mathrm{pH} 3.0$ and as the $\mathrm{pH}$ increased, the biosorption decreased. Since its chemical structure is hidden, the $\mathrm{pK}_{a}$ values of the functional groups of dye molecule cannot be known. Therefore, it's estimated that at lower $\mathrm{pH}$ values there may be an electrostatic attractions between charged dye molecules and charged cell surface.

\section{Effect of temperature on dye biosorption}

The temperature of the biosorption medium affected the equilibrium uptake of Sirius Blue K-FCN dye on lyophilized $T$. versicolor biomass. The effect of temperature on the equilibrium biosorption capacity 
was studied in the temperature range of $7-45^{\circ} \mathrm{C}$ at an initial dye concentration of $100 \mathrm{mg} \mathrm{I}^{-1}$. The optimum adsorption temperature was determined as $26^{\circ} \mathrm{C}$. As shown in Figure 3, the biosorption of the dye increased with increasing temperature up to $26^{\circ} \mathrm{C}$. The increase in biosorption could be due to increased surface activity and increased kinetic energy of the dye molecule (Aksu and Çağatay, 2006). The decrease in biosorption capacity of $T$. versicolor. above $26^{\circ} \mathrm{C}$ may be attributed to the deactivation of the biosorbent surface or the destruction of some active sites on the biosorbent surface. As a result, the optimum temperature for Sirius Blue K-FCN biosorption was chosen as $26^{\circ} \mathrm{C}$ for subsequent experiments.

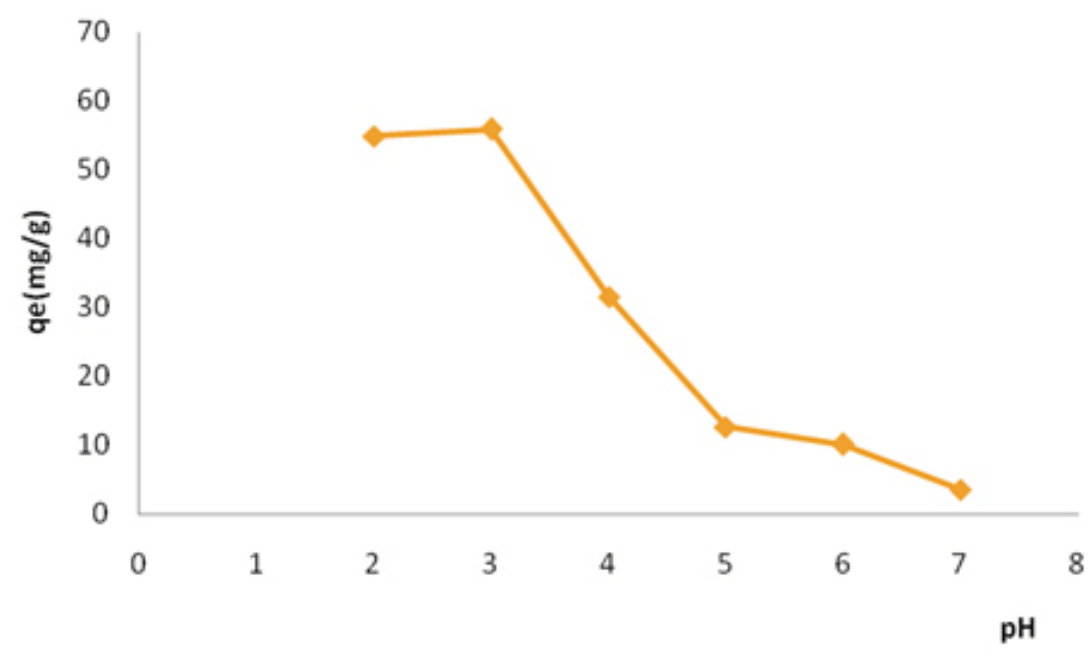

Fig. 2 The effect of initial $\mathrm{pH}$ on the equilibrium sorption capacity of $T$. versicolor $\left(C_{\mathrm{o}} 100 \mathrm{mg} \mathrm{I}^{-1}, X 1.2 \mathrm{~g} \mathrm{I}^{-1}\right.$, temperature $26^{\circ} \mathrm{C}$, agitation rate $150 \mathrm{rpm}$ ).

\section{Biosorption equilibrium time and isoterm models}

Adsorption equilibrium is established when the amount of solute being adsorbed on to the adsorbent is equal to the amount being desorbed. At this point, the equilibrium solution concentration remains constant.

In the present investigation the equilibrium data are analyzed using the Langmuir (Equation 1) and Freundlich isotherm expressions (Equation 2).

$q_{e q}=\frac{Q^{\circ} C_{e q}}{1+b C_{e q}}$

[Equation 1]

$Q^{\circ}$ and $b$ can be determined from the linear plot of $C_{\text {eq }} / q_{\text {eq }}$ versus $C_{\text {eq. }}$

$q_{\text {eq }}=K_{F} C_{e q}^{1 / n}$

[Equation 2] 
Equation 2 can be linearized in logarithmic form and Freundlich constants can be determined. The Freundlich isotherm is also more widely used but provides no information on the monolayer adsorption capacity, in contrast to the Langmuir model.

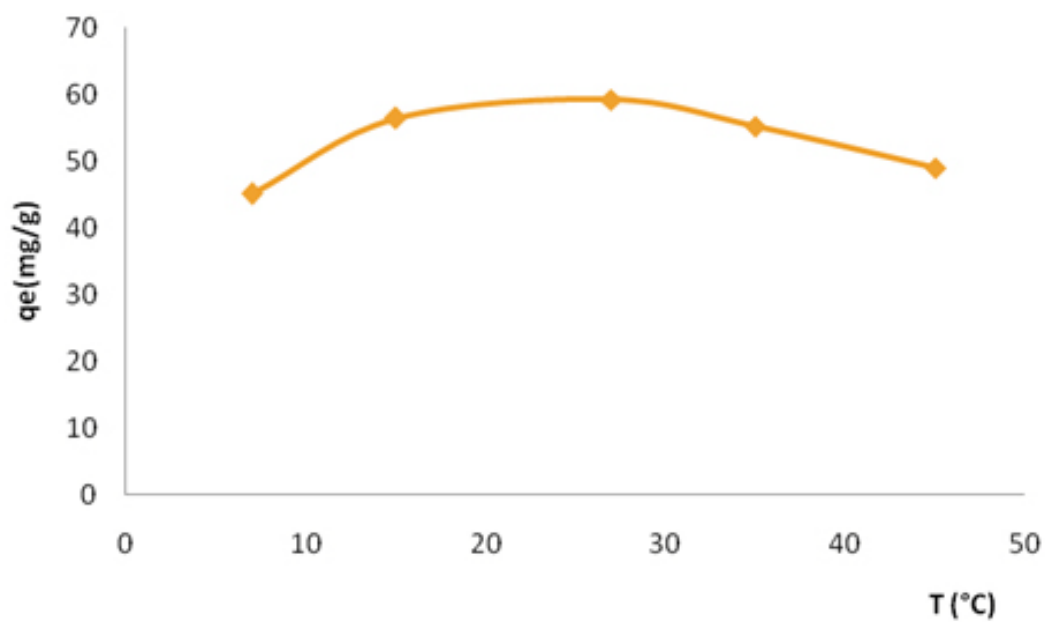

Fig. 3 The effect of temperature on the equilibrium dye sorption capacity of $T$. versicolor $\left(C_{0} 100 \mathrm{mg} \mathrm{I}^{-1}, X 1.2\right.$ $\mathrm{g} \mathrm{I}^{-1}, \mathrm{pH} 3.0$, agitation rate $\left.150 \mathrm{rpm}\right)$.

Figure 4 shows the effect of the time contact on Sirius Blue biosorption rate by $T$. versicolor biomass and Figure 5 shows Langmuir isotherms for adsorption of Sirius Blue. Based on the results, 120 min was taken on the equilibration time for Sirius Blue K-CFN in subsequent experiments. The great majority of biosorption was occured in one hour after first contact with dye and biomass. At the residual time biosorption was reached equilibrium within descending acceleration.

The Langmuir constants $Q^{\circ}$ and $b$ and the Freundlich constants $n, K_{f}$ are shown at Table 1. As seen from the Table 1, a linear relation was observed among the plotted parameters with the $R^{2}$ value of 0,968 and 0,727 for Langmuir and Freundlich isotherms, respectively. According to these results, Langmuir sorption isotherm more accurately describe the biosorption of Sirius Blue K-CFN onto lyophilized $T$. versicolor biomass since correlation coefficient of Langmuir model is higher than Freundlich model.

Table 1. A comparison of the Freundlich and Langmuir adsorption constants obtained from the Freundlich and Langmuir adsorption isotherms of Sirius Blue K-FCN dye.

\begin{tabular}{cccccc}
\hline & Langmuir constants & \multicolumn{3}{c}{ Freundlich constants } \\
$\mathrm{Q}^{\circ}\left(\mathrm{mg} \mathrm{g}^{-1}\right)$ & $\mathrm{b}(1 / \mathrm{mg})$ & $\mathrm{R}^{2}$ & $\mathrm{~K}_{\mathrm{F}}$ & $\mathrm{N}$ & $\mathrm{R}^{2}$ \\
200 & 3.6 & 0.968 & $3.57 \times 10^{-7}$ & 0.2287 & 0.727 \\
\hline
\end{tabular}

\section{Biosorption kinetics}

Biosorption studies indicate that increasing biosorbent dose provides more surface area for binding the dye molecule. In order to find out the rate-controlling steps involved in the process of biosorption of Sirius Blue on to T. versicolor biomass, both pseudo first-order (Equation 3) and pseudo second-order kinetic models (Equation 4) were used due to fit the experimental data. 


$$
\frac{\mathrm{d} q}{\mathrm{~d} t}=k_{1, \mathrm{ad}}\left(q_{\mathrm{eq}}-q\right)
$$

[Equation 3]

In most cases the first-order equation does not fit well for the whole range of contact time and is generally applicable over the initial 20-30 min of the sorption process (Liu and Liu, 2008).

$$
\frac{\mathrm{d} q}{\mathrm{~d} t}=k_{2, \mathrm{ad}}\left(q_{\mathrm{eq}}-q\right)^{2}
$$

[Equation 4]

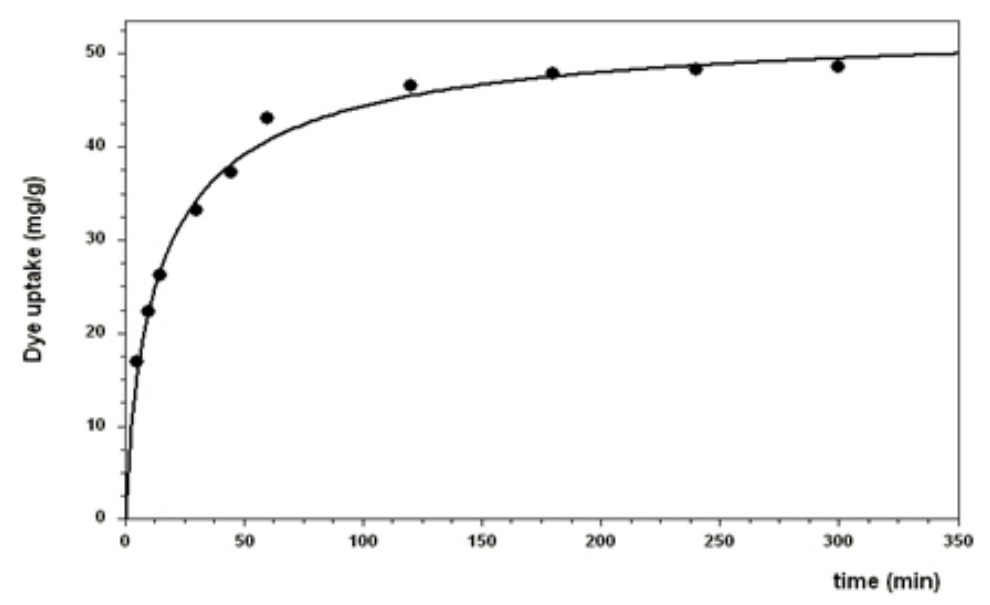

Fig. 4 Effect of the time contact on Sirius Blue (SB) biosorption rate by T. versicolor biomass.

The plots of $\log \left(q_{e q}-q\right)$ as a function of biosorption time are presented in Figure $6 a$ and the rate constants $k_{1 . a d}, k_{2, a d}$ and $R^{2}$ are presented at Table 2. The plots of $\left(t / q_{t}\right)$ as a function of biosorption time are shown in Figure $6 \mathrm{~b}$. As seen from Table 2, the magnitude of the regression coeffcient $R^{2}$ for the pseudo-first-order model and pseudo-second-order model are 0.98 and 0.999 , respectively. This implies that the Sirius Blue on to $T$. versicolor biomass does not follow first-order kinetic, but follow the pseudo-second-order kinetic models.

\section{Comparison with activated carbon and Amberlite XAD-7}

As shown in Figure 7, the biosorption capacity of lyophilized T. versicolor biomass for Sirius Blue KFCN was $62.62 \mathrm{mg} / \mathrm{g}$ at the equilibrium time (2 hrs) whereas the biosorption capacity for activated carbon and Amberlite XAD-7 were 31.77 and $4.69 \mathrm{mg} / \mathrm{g}$ respectively. This comparative study indicates that lyophilized $T$. versicolor biomass is more effective than Amberlite XAD-7 and activated carbon for removing the dye from an aqueous solution under the same conditions.

Table 2. The rate constants of first order and second order adsorption kinetic models.

\begin{tabular}{cccc}
\hline \multicolumn{2}{c}{ Pseudo-First order adsorption } & \multicolumn{2}{c}{ Pseudo-Second order adsorption } \\
$\mathrm{K}_{1, \mathrm{ad}}$ & $\mathrm{R}^{2}$ & $\mathrm{~K}_{2, \text { ad }}$ & $\mathrm{R}^{2}$ \\
0.01935 & 0.98 & 0.00195 & 0.999 \\
\hline
\end{tabular}




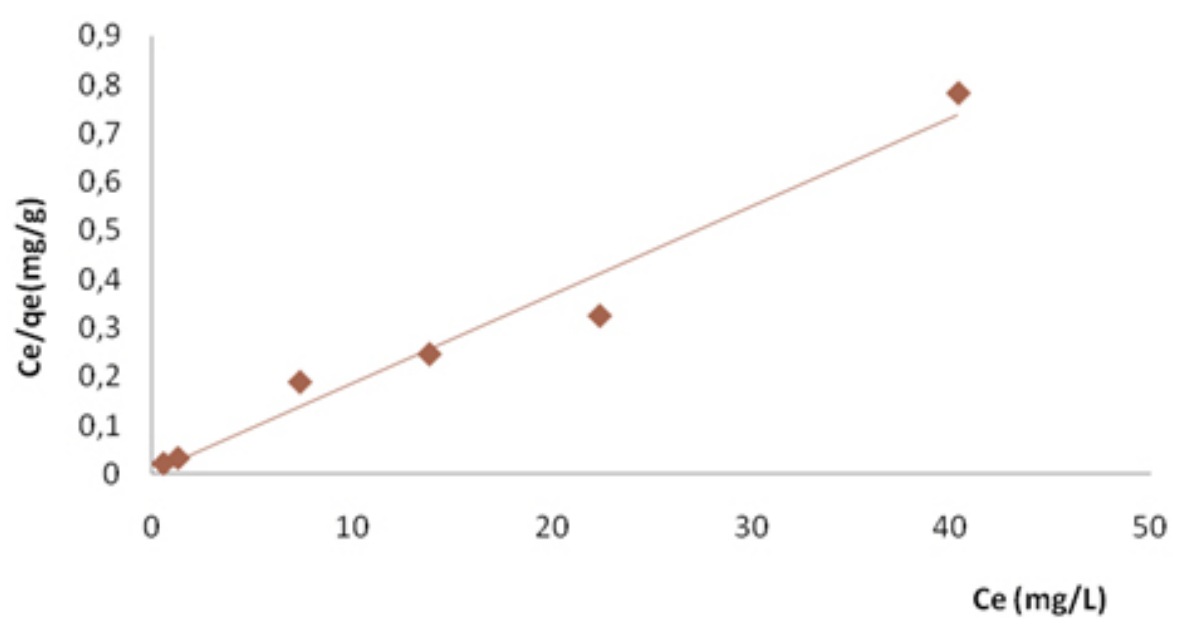

Fig. 5 Langmuir isoterms for adsorption of Sirius Blue K-CFN.

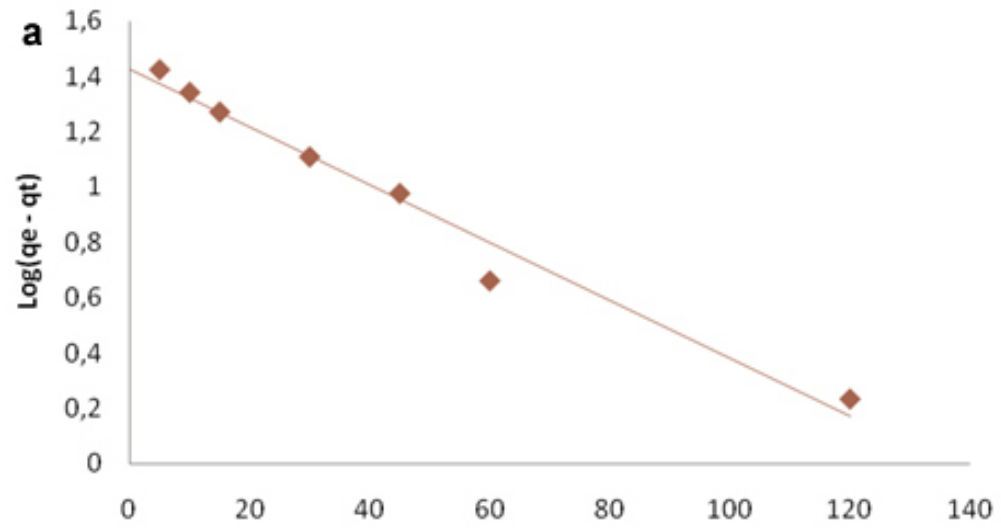

b

time (min)

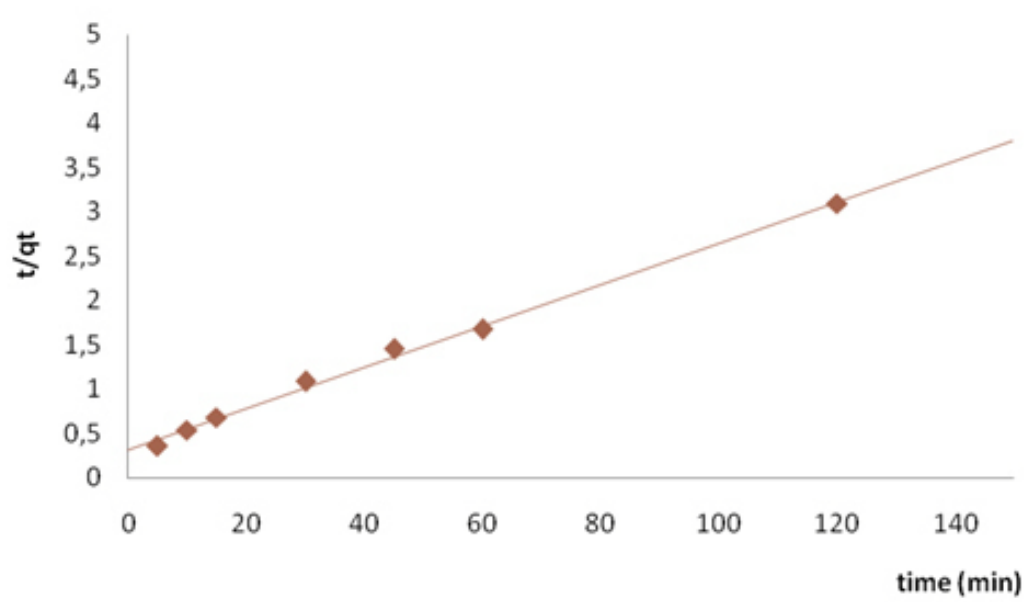

Fig. 6 Plots of sorption kinetic equations for SB sorption by T. versicolor biomass. (a) Pseudo first-order kinetic. (b) Pseudo second-order kinetic. 


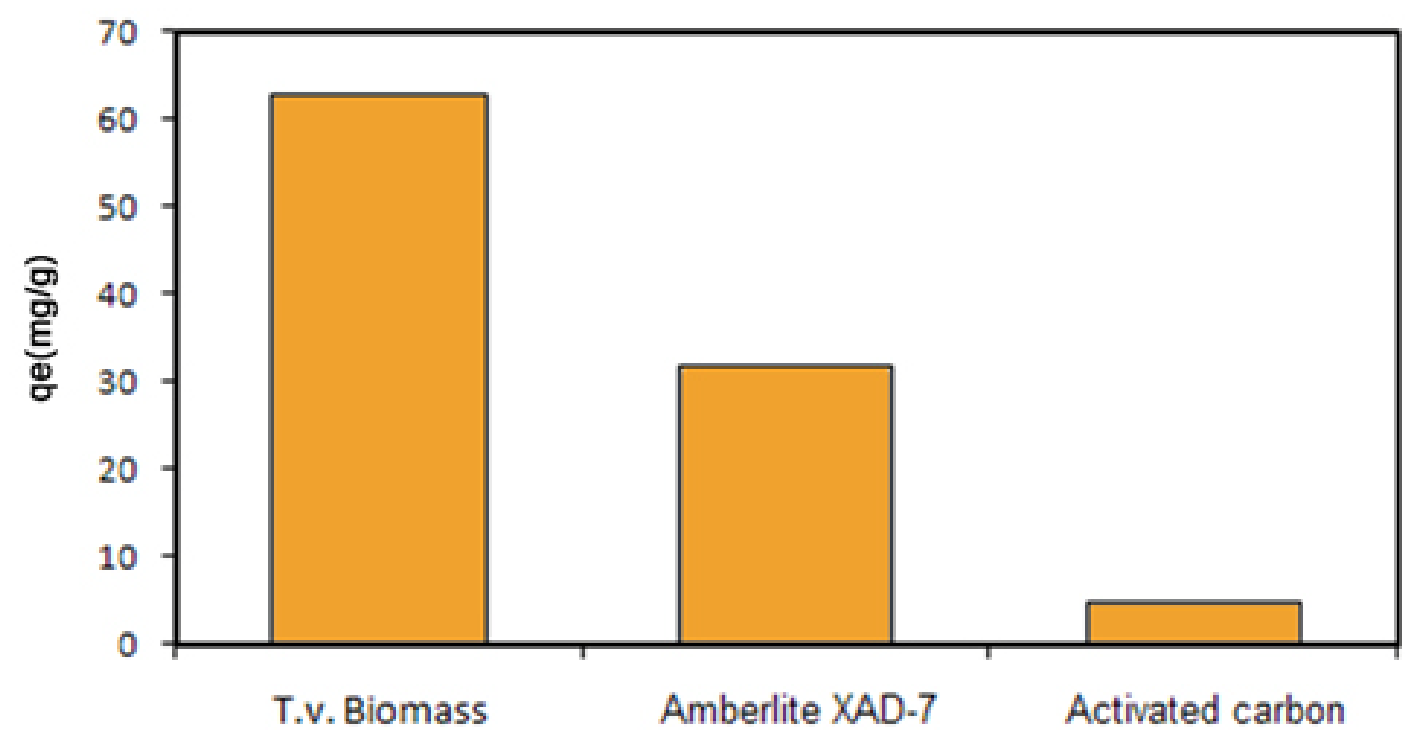

Fig. 7 Comparison of the sorbents via sorption capacity under the same conditions with $T$. versicolor biomass.

\section{CONCLUDING REMARKS}

Our previously biodegradation studies have demonstrated that some of the textile dyes could have removed from the effluent by Trametes versicolor due to biosorption in the short term (Pazarlioglu et al. 2010). Therefore, in this study, the biosorption of Sirius Blue K-CFN dye was investigated by using a lyophilized $T$. versicolor biomass as a biosorbent. The experimental data indicates that medium $\mathrm{pH}$, temperature and biosorbent concentration play a significant role in biosorption of the dye.

Results obtained from this study showed that lyophilized $T$. versicolor was very effective as a biosorbent material for the removal of Sirius Blue K-CFN dye from aqueous solutions compared with other sorbents such as activated carbon and Amberlite XAD-7.

\section{NOMENCLATURE}

B Langmuir adsorption constant $\left(1 \mathrm{mg}^{-1}\right)$

$C_{\text {eq }} \quad$ Residual dye concentration at equilibrium $\left(\mathrm{mg} \mathrm{l}^{-1}\right)$

$C_{0} \quad$ Initial dye concentration $\left(\mathrm{mg}^{-1}\right)$

$k_{1, \text { ad }} \quad$ First-order adsorption rate constant $\left(\mathrm{min}^{-1}\right)$

$k_{2, \text { ad }} \quad$ Second-order adsorption rate constant $\left(\mathrm{g} \mathrm{mg}^{-1} \mathrm{~min}^{-1}\right)$

$K_{\mathrm{F}} \quad$ Freundlich adsorption constant

$N \quad$ Freundlich adsorption constant

Q Adsorbed dye quantity per gram of biomass at any time $\left(\mathrm{mg} \mathrm{g}^{-1}\right)$

$q_{\mathrm{eq}} \quad$ Adsorbed dye quantity per gram of biomass at equilibrium $\left(\mathrm{mg} \mathrm{g}^{-1}\right)$

$Q^{\circ} \quad$ Langmuir adsorption constant $\left(\mathrm{mg} \mathrm{g}^{-1}\right)$

$R^{2} \quad$ Correlation coefficient

$X \quad$ Biomass concentration $\left(\mathrm{g} \mathrm{I}^{-1}\right)$ 


\section{REFERENCES}

AKAR, S.T.; GORGULU, A.; KAYNAK, Z.; ANILAN, B. and AKAR, T. (2009). Biosorption of Reactive Blue 49 dye under batch and continuous mode using a mixed biosorbent of macro-fungus Agaricus bisporus and Thuja orientalis cones. Chemical Engineering Journal, vol. 148, no. 1, p. 26-34. [CrossRef]

AKSAKAL, O. and UCUN, H. (2010). Equilibrium, kinetic and thermodynamic studies of the biosorption of textile dye (Reactive Red 195) onto Pinus sylvestris L. Journal of Hazardous Materials, vol. 181, no. 1-3, p. 666-672. [CrossRef]

AKSU, Z. (2005). Application of biosorption for the removal of organic pollutants: A review. Process Biochemistry, vol. 40, no. 3-4, p. 997-1026. [CrossRef]

AKSU, Z. and TEZER, S. (2005). Biosorption of reactive dyes on the green alga Chlorella vulgaris. Process Biochemistry, vol. 40, no. 3-4, p. 1347-1361. [CrossRef]

AKSU, Z. and ÇAĞATAY, Ş.Ş. (2006). Investigation of biosorption of Gemazol Turquise Blue-G reactive dye by dried Rhizopus arrhizus in batch and continuous systems. Separation and Purification Technology, vol. 48, no. 1, p. 24-35. [CrossRef]

BATZIAS, F.A. and SIDIRAS, D.K. (2007). Dye adsorption by prehydrolysed beech sawdust in batch and fixed-bed systems. Bioresource Technology, vol. 98, no. 6, p. 1208-1217. [CrossRef]

BAYRAMOĞLU, G. and ARICA, M.Y. (2007). Biosorption of benzidine based textile dyes "Direct Blue 1 and Direct Red 128" using native and heat-treated biomass of Trametes versicolor. Journal of Hazardous Materials, vol. 143, no. 1-2, p. 135-143. [CrossRef]

BHOLE, B.D.; GANGULY, B.; MADHURAM, A.; DESHPANDE, D. and JOSHI, J. (2004). Biosorption of methyl violet, basic fuchsin and their mixture using dead fungal biomass. Current Science, vol. 86, no. 12, p. 16411645.

CALVETE, T.; LIMA, E.C.; CARDOSO, N.F.; DIAS, S.L.P. and PAVAN, F.A. (2009). Application of carbon adsorbents prepared from the Brazilian pine-fruit-shell for the removal of procion red $M X 3 B$ from aqueous solution-kinetic, equilibrium, and thermodynamic studies. Chemical Engineering Journal, vol. 155, no. 3, p. 627-636. [CrossRef]

CRINI, G. (2006). Non-conventional low-cost adsorbents for dye removal: A review. Bioresource Technology, vol. 97, no. 9, p. 1061-1085. [CrossRef]

FU, Y. and VIRARAGHAVAN, T. (2003). Column studies for biosorption of dyes from aqueous solutions on immobilised Aspergillus niger fungal biomass. Water SA, vol. 29, no. 4, p. 465-472.

KIRAN, I.; ILHAN, S.; CANER, N.; ISCEN, C.F. and YILDIZ, Z. (2009). Biosorption properties of dried Neurospora crassa for the removal of Burazol Blue ED dye. Desalination, vol. 249, no. 1, p. 273-278. [CrossRef]

KUMARI, K. and ABRAHAM, T.E. (2007). Biosorption of anionic textile dyes by nonviable biomass of fungi and yeast. Bioresource Technology, vol. 98, no. 9, p. 1704-1710. [CrossRef]

LIANG, S.; GUO, X.; FENG, N. and TIAN, Q. (2010). Isotherms, kinetics and thermodynamic studies of adsorption of $\mathrm{Cu}^{2+}$ from aqueous solutions by $\mathrm{Mg}^{2+} / \mathrm{K}^{+}$type orange peel adsorbents. Journal of Hazardous Materials, vol. 174, no. 1-3, p. 756-762. [CrossRef]

LIU, Y. and LIU, Y.J. (2008). Biosorption isotherms, kinetics and thermodynamics. Separation and Purification Technology, vol. 61, no. 3, p. 229-242. [CrossRef]

MAURYA, N.S.; MITTAL, A.K.; CORNEL, P. and ROTHER, E. (2006). Biosorption of dyes using dead macro fungi: Effect of dye structure, ionic strength and pH. Bioresource Technology, vol. 97, no. 3, p. 512-521. [CrossRef]

MOHAN, S.V.; RAMANAIAH, S.V. and SARMA, P.N. (2008). Biosorption of direct azo dye from aqueous phase onto Spirogyra sp. 102: Evaluation of kinetics and mechanistic aspects. Biochemical Engineering Journal, vol. 38, no. 1, p. 61-69. [CrossRef]

PATEL, R. and SURESH, S. (2008). Kinetic and equilibrium studies on the biosorption of reactive black 5 dye by Aspergillus foetidus. Bioresource Technology, vol. 99, no. 1, p. 51-58. [CrossRef]

PAZARLIOGLU, N.K.; AKKAYA, A.; AKDOGAN, H.A. and GUNGOR, B. (2010). Biodegradation of Direct Blue 15 by free and immobilized Trametes versicolor. Water Environment Research, vol. 82, no. 7, p. 579-585. [CrossRef]

PERUMAL, S.M.; MUNUSWAMY, D.; SELLAMUTHU, P.S.; KANDASAMY, M. and PUTHUPALAYAM, K.T. (2007). Biosorption of textile dyes and effluents by Pleurotus florida and Trametes hirsuta with evaluation of their laccase activity. Iranian Journal of Biotechnology, vol. 5, no. 2, p. 114-118.

RENGANATHAN, S.; THILAGARAJ, W.R.; MIRANDA, L.R.; GAUTAM, P. and VELAN, M. (2006). Accumulation of Acid Orange 7, Acid Red 18 and Reactive Black 5 by growing Schizophyllum commune. Bioresource Technology, vol. 97, no. 16, p. 2189-2193. [CrossRef]

RUSSO, M.E.; DI NATALE, F.; PRIGIONE, V.; TIGINI, V.; MARZOCCHELLA, A. and VARESE, G.C. (2010). Adsorption of acid dyes on fungal biomass: Equilibrium and kinetics characterization. Chemical Engineering Journal, vol. 162, no. 2, p. 537-545. [CrossRef]

SADETTIN, S. and DÖNMEZ, G. (2006). Bioaccumulation of reactive dyes by thermophilic cyanobacteria. Process Biochemistry, vol. 41, no. 4, p. 836-841. [CrossRef]

YANG, X.Q.; ZHAO, X.X.; LIU, C.Y.; ZHENG, Y. and QIAN, S.J. (2009). Decolorization of azo, triphenylmethane and anthraquinone dyes by a newly isolated Trametes sp. SQ01 and its laccase. Process Biochemistry, vol. 44, no. 10, p. 1185-1189. [CrossRef]

YESILADA, O.; ASMA, D. and CING, S. (2003). Decolorization of textile dyes by fungal pellets. Process Biochemistry, vol. 38, no. 6, p. 933-938. [CrossRef] 


\section{How to cite this article:}

ERDEN, E.; KAYMAZ, Y. and PAZARLIOGLU, N.K. (2011). Biosorption kinetics of a direct azo dye Sirius Blue K-CFN by Trametes versicolor. Electronic Journal of Biotechnology, vol. 14, no. 2. http://dx.doi.org/10.2225/vol14-issue2-fulltext-8 